\title{
Barriers and Countermeasures on the Implementation of Executive Stock Options in Chinese Listed Corporations
}

\author{
Wangxia Liu', Yunjin Tan ${ }^{2}$ \\ School of Economics and Management, Hubei University of Education, Wuhan, China \\ ${ }^{1}$ lwxletter@126.com, ${ }^{2}$ tanyunjin@whpu.edu.cn
}

\begin{abstract}
As a long-term incentive plan, the theory of Executive Stock Options is theoretically perfect. However, there are some obvious implementation obstacles on its stimulating impact in some field, such as legislation, market, supervision, assessment, tax preference and so on. Therefore, this paper analyzes the barriers of Executive Stock Options and its countermeasures by using comparative analysis method, empirical analysis method and case analyzing method aiming at enhancing the incentive effect on the implementation of Executive Stock Options in Chinese listed corporations. Finally, it is concluded that such countermeasures should be taken as follows: Establishing and improving laws and regulations about the stock options, setting up scientific evaluation system, reinforcing the supervision dynamics of intermediary service institutions, industriously enhancing the effectiveness of security markets of China and providing the support on tax policy etc.
\end{abstract}

Index Terms - Executive Stock Options; listed corporations, legislation obstacles; evaluation index; stock market.

\section{Executive Stock Option and its Related Theory Foundation}

Executive Stock Option (ESO) is an arrangement that grants the senior management or technique backbone the right to purchase the specified number of shares of the company at a fixed price according to the contract between the executives and the company in the future period which is generally 3-5 years or longer after the contract is signed. It is the most basic form of the stock option system, originating from the United States of America in 1950s. The encouraged executives can exercise the rights or give up the rights, except for transferring, collateralizing or repaying of a debt over the period of contract. That's to say, if the stock price of the company goes up, the executive can exercise the options to buy the shares at the fixed price, sell the shares at the market price, and then get benefit. [1].

It has been widely held that agency costs are reduced by relating an executive's compensation to firm performance [2]. Executive stock option schemes have been identified as a means to reduce the agency problems between managers and stockholders and now have become a popular component of managerial compensation packages [3].

The theoretical foundation of ESO is mainly the theories of entrust-agent and human capital property right. According to the entrust-agent theory, shareholders as the principals and executives as the agents haven't consistent benefits and objectives. Due to the asymmetry of information, the executives may utilize the information superiority to take actions which damaged the interests of shareholders.
Therefore, the principals must provide appropriate incentives for the agent to reduce the interest divergence between them, including the distribution of benefits and rewards etc., confirming the rights and responsibilities of both parties and promoting the maximum interest of the principals when the agents pursue the maximization of their utility. Similarly, based on the theory of human capital property right, the modern enterprise is a complicated treaty between the ownership of financial capital and that of human capital. That's to say, the human capital should have the property right of human capital, participating in the allocation of enterprise residual income [4].

The ESO is conducive to establishing and improving the modern enterprise system, reducing agency costs, and cultivating the occupation managers etc. It is perfect in theory, but there are many obstacles in practice. This paper discussed the obstacles and countermeasures on the implementation of the ESO in Chinese listed corporations.

\section{Barriers on the Implementation of ESO in Chinese Listed Corporations}

ESO was introduced into China at the beginning of 1990s. The Vanke Group of Shenzhen was the earliest company of China to implement the system similar to ESO in 1993. In 1997, the Four Tongli Company imported the ESO from USA. Chinese Securities Regulatory Commission (CSRC) announced the "Administrative Measures of Equity Incentive of Listed Corporations" to Chinese listed corporations in 4th January, 2006, after which ESO developed in China. As the long-term incentive and constraint methods and mechanism, ESO hasn't been implemented effectively in China because of the influence of various factors [5]. By comparing the conditions before and after the implementation of ESO in Chinese listed corporations, we found that the profit growth, asset growth and management efficiency did not reach the expected effect and purpose after implementing ESO. There are many barriers on the implementation of ESO in the listed corporations of China.

\section{A. Obstacle of Law on Stock Source}

Perhaps the biggest deterrent of implementing ESO is the ambiguity in its associated laws. The promulgation of regulations such as new "company law", new "Securities Law" and "Administrative Measures of Equity Incentive of Listed Corporations(Trial)" etc. offset the gaps of law in 2006, which became the basis of implementing ESO and made it more standardized. According to the international 
conventions, the reserved shares and repurchased shares of the company are the main ways to realize the stocks that ESO needs. But the two channels in China are still limited. The relevant provisions of "Company law" required that companies can't purchase and hold the company's shares. What's more, the listed company can't repurchase the shares of the company. Though there were some companies that implemented ESO to repurchase their own shares to reward the senior managers in the name of individual workers, which still belonged to violating or evading the provisions of "company law" [6].

\section{B. Unsound Stock Market and Manager Market}

There must be a sound stock market to realize the incentive to managers. Nevertheless, the listed companies and the operators of securities seriously violated and damaged the interest of investors in the stock market of China. What's more, the stock price did not reflect the value of the company, so it couldn't reflect managers' ability and efforts, and then the stock market lost the function of evaluating executives. At the same time, the manager markets were not really established, the problem of selection mechanism of managers could not be fundamentally solved. At present, the board of state-owned listed corporation is operated by the state-owned shareholders and the main operators of the company are appointed by the state-owned shareholders, rather than from the selection of the manager markets. So the operators are only responsible for the superior authorities and their administrative instructions, not in charge of the enterprise, which ultimately affected the effect of ESO.

C. Imperfect Accounting System and Confusing Option Incentive

There need be perfect accounting system on the implementation of ESO. Up to now the accounting system is far away from perfect, which leads to many loopholes to be utilized in the practice of accounting system. Therefore, this caused the unobvious incentive function or loss of enterprise benefit. There are general issues of chaos of ESO in the listed corporations. According to statistics, more than 30 listed corporations launched the equity incentive program since 2010 and there were 9 listed corporations announcing the plans only in June 2010, among which many listed corporations selected the ESO. However, it was founded that the parameters which the listed companies use to estimate the fair value were myriad, and the problems of information asymmetry also existed. Furthermore, the great deviation on understanding of accounting standards happened in the individual companies [7].

D. Lack of Supervision and Scientific Evaluation Index System

The present intermediary institutions such as accountant firms, auditor firms and assessment organization etc. have poor independence, and they failed to make objective business activities and could not effectively carry out their supervision, which weakened the effect of implementation of ESO. For example, the serious phenomenon that the profit and price was manipulated in the listed corporations had relation with the lack of supervision of intermediary institutions and security markets. In practice, there are many assessment indicators of ESO, but they are mainly the traditional performance evaluation indicators, such as net profit after tax, earnings per share, rate of return on net assets and asset-liability ratio, which can not accurately reflect the value of the company. Moreover, there isn't a sound and scientific evaluation system. How to determine the performance appraisal system of enterprise and how to motivate the relation with ESO need be further improved.

E. Problem of Preferential Tax of ESO

In China, there is not special tax preferential measures on ESO at present. Furthermore, the shares that the executives hold are subjected to the locked-up period during which they cannot sell their shares, so ESO is not more attractive than salaries. Under the current policy, the difference between the closing share price and exercising price of ESO on the vesting date should be taxed according to "wage, salary income" as personal income tax, which makes the marginal tax rates that the executives undertake can be $45 \%$ even higher, The high tax burden may result in managers' insolvency to the huge personal income tax generated by exercising the ESO [8].

There are other barriers on the implementation of ESO, including risk that managers need undertake, foreign exchange system (when ESO comes from transnational corporations ;) and the change of objective conditions and so on. ESO sometimes makes managers undertake too much risk [9]. Henan Diamond Stock Company of Zhengzhou (referred to as "the company") held the second board of directors on 27, June, 2013, examining and adopting the "Proposal on the termination of ESO plan". The reason of termination of ESO plan is that domestic macro-economic situation and capital market environment have changed largely since the plan of ESO was considered by the board of directors in 2010. Meanwhile the company's share price is lower than the exercising price, if ESO plan continues to be implemented it will be very difficult to reach the expected effect [10].

\section{Countermeasure on implementing effectively the ESO in listed companies}

On the base of the barriers and reasons of implementation of ESO in the listed companies above, these countermeasures should be taken as follows:

\section{A. Establishing and Improving laws and Regulations on ESO}

In foreign countries, a series of standard legal system has been established from the design to the application of ESO. For example, the scope of beneficiaries, the number of options, determination of the exercise price, implementation methods and definite regulations of law. In view of this, we should establish and improve the relevant laws and regulations of ESO in China as follows: 1) Formulating regulations of law on ESO as soon as possible. The objects of implementation of ESO, implementation time, quantities, time restrict and management etc. should be regulated, which should be the basis of implementing ESO and will be more applicable to the practice of ESO. 2) Modifying the contents of the current laws 
and regulations which are not applicable to ESO. These modified contents contain allowing companies to buy back shares not decreasing the capital of company and allowing the authorized persons to sell the appropriate proportion of ESO held by the authorized during the terms of office after reaching the appointed time. 3) Establishing the reduction law of the state-owned shares. According to the reduction law, the state-owned shares of reduction is used as the source of funds of ESO, one part of which can be used to establish the ESO system, the other part of which can be used to establish the plan of share ownership of employees. That the state-owned shares of reduction are turned into manager shares, accompanied by other forms such as employee share ownership etc. is conducive to establish the diversified investment subjects, conducive to weakening the insider control and improving the corporate governance structure, and beneficial to the long-term sustainable development of companies [11].

\section{B. Improving the Accounting System and Strengthening the Supervision}

The accounting system of China should be further improved. Comprehensive regulation of ESO in Chinese listed corporations should be made about accounting rules, accounting regulations, accounting treatment, information disclosure and financial supervision etc. In the light of the problems of the poor supervision and independence etc. existing in the implementation of ESO, the government should make the intermediary service agencies continuously improve and develop, define legal responsibility, practice objectively and impartially fulfill their functions in order to carrying out the effective supervision on the implementation of ESO. In particular, the financial supervision need be strengthened in order to avoid the happening of nonstandard behavior that managers of listed corporations manipulate stock price and profits.

\section{Enhancing the effectiveness of securities market in China}

Incentive function of ESO and its implementation depend on the effectiveness of stock market. The stock market should be further improved to make the stock price really reflect the performance of the company. The stock price is the external reflection of the company value. the stock option is in essence the evaluation information about the performance of company and growth potential extracted from the stock price of company of the stock market, which is used to encourage senior managers to pay more attention to the long-term sustainable development of company. In the efficient stock market, stock price can reflect the operating status and future profitability of company, thus it has the strong function of evaluation on the performance of senior managers. The main measures to regulate the development of stock market are to establish and strictly implement the compulsory information disclosure system, create an open, fair and justice stock market. The responsible persons who have illegal activities such as keeping the truth from the listed corporations and intermediary institutions and providing the false information and going in for insider trading etc. must be severely punished by the government according to the law.

\section{Accelerating the Development of Manager Market and Building a Scientific Evaluation System}

Accelerating the development of manager markets is the most urgent item to implement the ESO at present in China. In accordance with the requirements of the market economy, the system of appointed managers by the administrative institutions should be abolished gradually. Market selection mechanism of managers should be established rapidly, forming the market employment mechanism of fairness, competition and the survival of the fittest, and establishing authoritative qualification evaluation center of managers, thus forming the effective incentive and restraint mechanism to managers. Especially, it is essential to set up the information platform of managers which provides adequate record of qualifications, skills, business performance and credit of professional managers to potential employers who want to find suitable agents.

At the same time, we should establish scientific performance evaluation system to promote the implementation of ESO effectively. The performance evaluation should be concretion, objectification on the basis of standard, fairness and justice as far as possible. The successful experience of the United States and other countries can be learned by China to set up the evaluation index of manager performance such as economic value added (EVA) etc. to encourage managers to create greater value for shareholders. In addition, the listed corporations can use the index system combined with a variety of indexes, incorporating the main business profit, operating cash flow, turnover rate of accounts receivable, turnover rate of inventory etc. into the evaluation index system to carry out comprehensive evaluation.

\section{E. Offering the Support on Tax Policy}

In order to make ESO play its long-term incentive effect, main countermeasures can be taken as follows: 1) appropriately reduce the tax rate of incentive income of ESO. The income that the objects gain through ESO should be lower than the tax rate of wages and salaries. Reduction of Tax will attract the incentive object transferring from the preference of cash income to that of ESO, thus encouraging the further development of ESO in China. 2) Changing the time of. tax obligation. If tax of ESO occurs when the shares are transferred, the cost of shares held by the incentive objects and the risk of losses caused by the falling of stock price will be reduced, so as to encourage the objects to hold the company stock for a long-term. 3) Matching the tax rate and the held time of shares. When the incentive objects hold the company shares for longer time, the lower grades of tax rate will be applied, encouraging the holding of long term of stocks to achieve long-term incentive effect. 4) Extending the amortization period to reduce the tax burden of the incentive object. At present, the "Law on Personal Income Tax" for the tax burden of stock option gains is still heavy and its benefits are stated for 12 months, which produce high progressive tax 
rate and reduce the actual effect. So the tax should be different for different listed companies. The amortization period of benefit should be extended for the listed companies of high growth to reduce the tax burden of the incentive object. In the meantime, the income tax of listed corporation should be certainly preferential [12].

Of course, the exchange system must be reformed further. In addition, the held quantity of the option and applicability of the option system should also be considered. The quantity of option should be appropriate, otherwise it will be difficult to achieve the incentive effect. Furthermore, ESO system can not apply to all industries and companies. For example, it does not apply to the state-owned listed corporations of monopoly, because the firm performance can't reflect the real performance of effort and ability. But the companies in the hitech industry and the growth stage are easy to be pursued by investors, and the stock price will rise up sharply, the incentive effect will be apparent. Nevertheless, the incentive effect will be unobvious for the companies in the sunset industry or in the recessing stage.

In the long term, with the capital market gradually standardized, occupation manager market gradually perfect and the gradual improvement of policies and regulations, the stock option system is the good forms of long-term incentive. But we should notice that the stock option system is not omnipotent and the system itself has many defects in the application. Therefore, Chinese enterprises should seriously carry on analysis and study deeply on this, preparing for the smooth implementation of stock option system.

\section{Acknowledgment}

In this paper, the research was sponsored by the Research Fund Project of Key Disciplinary Construction of Applied Economics Directly Cultivated by Hubei Province in Hubei University of Education and the Fund Project (Project No.Q20123102) of Science and Technology of Education Department of Hubei Province.

\section{References}

[1] Richard A. Defusco, Robert R. Johnson, and Thomas S. Zorn, "The effect of executive stock option plans on stockholders and bondholders," The Journal of Finance, vol. 45, no. 2, pp. 617-627, June 1990.

[2] Michael C. Jensen and William H. Meckling, "Theory of the firm: managerial behavior, agency costs and ownership structure," Journal of Financial Economics, vol. 3, no. 4, pp. 305-360, October 1976.

[3] Pavlik, E.L., T.W. Scott, and P. Tiessen, "Executive compensation issues and research," Journal of Accounting Literature, vol. 12, pp.131-189, 1993.

[4] Qiren Zhou, "Enterprise in the markets: special treaty between human capital and non-human capital,” Economic Research, no.6, June 1996.

[5] Martin J. Conyon, Lerong He, "Executive compensation and corporate governance in China," Journal of Corporate Finance,vol. 17, Issue 4, pp.1158-1175, September 2011.

[6] Law Express, "The newest company law, " http://www.lawtime.cn/info/gongsi/gsfxglaw/20110323106616.html,0106-2012.

[7] Economic report of the twenty-first century, "Chaos of equity incentive of listed corporation and myriad returns without the risk," http://www.sina.com.cn, 17-06-2010.
[8] Ziqing Xu, "Optimization thought on the executive stock option system of listed corporations of China," The Modern Management Science, no. 4, pp. 42-44, April 2010.

[9] Zhiyong Dong, Cong Wang, Fei Xie, "Do executive stock options induce excessive risk taking?” Journal of Banking \& Finance, vol. 34, Issue 10, pp.2518-2529, October 2010.

[10]Financial network of China, "Henan diamond: announcement on the termination of the stock option incentive plan," http://www.cfi.net.cn/20130628002192.html, 28-06-2013.

[11]Lili Deng, "Study on the legal problems of the incentive mechanism of stock option in the listed corporations of China," Social Science Academy of China, master paper, pp. 1-46, 2012.

[12] Mi Liu, The present situation and policy suggestions of the development of stock option Incentive-take the GEM for example, paper of doctor degree, pp.47-52, 2013. 